\title{
Faculty readiness for a digital education model: A self- assessment from health sciences educators
}

\author{
Silvia Lizett Olivares Olivares, Mildred Lopez, Roman Martinez, Juan Pablo Nigenda Alvarez, \\ Jorge E. Valdez-García \\ Tecnologico de Monterrey
}

During the COVID-19 pandemic, the continuity of education across the world is being supported through e-learning. Healthcare programs especially, require continuing patientcentered training to benefit individuals and society. The objective of this study was to assess the faculty members' skills to continue educational services through a digital education model at the beginning of the lockdown. The methodology consisted in a quantitative approach descriptive and cross-sectional design. The instrument was a survey with two sections: (1) self-assessment and (2) self-ranking based on the digital education model. The results for 497 participants indicated higher scores on active learning and web conference digital skills. Evaluation is still a competence required to be reinforced by the faculty to incorporate a full transition into online learning. There seems to be an agreement about faculty readiness to implement different active learning strategies, despite being in a distance education model.

\section{Implications for practice:}

- University leaders welcomed the self-assessment that faculty members performed on digital skills as it allowed them to adapt the training programs and designate staff teams to support the educators once classes restarted.

- Educators implementing a digital education model should consider a planned and structured educational solution that is beyond the distance between learners and teachers, but an engaging environment for learning incorporating different technologies and active pedagogies.

Keywords: educational innovation; professional education; online learning, faculty development; digital education; medical education

\section{Introduction}

The discussion about the advantages of remote learning models emphasises the flexibility of studying wherever the learner is, and the possibility of connecting with peers from other cultures or nationalities. As learners do not need a physical classroom or infrastructure to enable attendance, prices for these educational models are more affordable often leading to a misconception that it is low-end version of training. This misconception reflects the lack of understanding of the complexity of the model. In fact it needs to incorporate more resources to mirror the basic tasks that would take place in a face-to-face model. Simple activities such as checking attendance, delivering an assignment, or being available to provide feedback, now require an investment in educational resources and an educator ready to tackle the challenge.

\section{Literature review}

The discussion about the contribution of these models is not new. As early as the 1990s, Galusha (1997) described barriers to the incorporation of distance education in adult learners such as the loss of motivation because of lack of face-to-face contact, the lack of technical assistance for both learners and educators, and the prohibitive costs of start-up the model (Galusha, 1997). Later, King et al. (2001) presented a differentiated definition between distance learning and distance education based on the description of instruction, exploration, and serendipity. They described distance education as a subcategory of instruction, in which learners and educators do not share a time and space context but are constrained by mediated technology. Another interesting insight by King et al. (2001)is that distance education allows extended time for reflection before submitting work or answering, use of resources without interrupting the flow of discussion, and a permanent recording of many interactions. 
Nevertheless, in early 2000 or even a year ago, no one thought that higher education was going to rely on a distance learning model to train a generation of learners. In March 2020, education faced one of the biggest challenges that has been encountered so far. Students and faculty members had to abruptly evolve from their face-to-face educational environments to a remote learning setting (Valdez et al., 2020). Most educational institutions were not prepared for this since planning and leadership approaches require gradual transitions to introduce new technology and pedagogical methodologies (López \& Valdez-García, 2019). However, higher education institutions with some experience with distance programs had the advantage of transforming courses into online learning models. Those institutions integrated their available infrastructure, engaged students in online education, and invited educators to apply their technology skills (López Cabrera et al., 2019; Sandars et al., 2020).

Healthcare programs were required to continue patient-centered training despite the pandemic to benefit individuals and society. Medical schools have the social responsibility to continue the education to assist and care for the needs that emerges in the community. As an institution, they might guide healthcare professionals, students, and faculty members for prevention and collaboration to battle COVID-19 impacts (Abreu-Hernández et al., 2020). Remote education models suddenly became the conduit to promote values and professional culture to engage academic, social, and research projects to benefit their profession's community and legacy (López et al., 2020).

There is an essential difference between emergency remote teaching and online learning. Emergency remote teaching is a temporary solution to the immediate COVID-19 pandemic (Bozkurt \& Sharma, 2020). In contrast, online learning is a planned and structured educational solution, such as the presence-based models, with the only difference being that there is a time or distance space between learners and teachers. As educational institutions become environments centered on active learning, distance education models still needed to be able to reflect that. Medical schools remained in lockdown for several months, so it became imperative that faculty members evolved any emergency remote teaching towards quality online learning models that considered adequately these active pedagogical methodologies (Bates, 2020; PeñaMartínez \& López, 2021).

This study aimed to assess the faculty members' skills to continue educational services through a digital education model at the beginning of the lockdown, through an online survey targeting faculty members from the School of Medicine and Health Sciences, at Tecnologico de Monterrey.

\section{Digital education model}

A quality digital-age approach is based on the interaction between the student and faculty member, each one responsible for part of the teaching-learning processes (Figure 1). Learning is student-directed, and it is built through communication and interaction with peers and faculty, engagement in active learning, and performance evaluation. Teaching, mostly educator-directed, relies on web conferencing for synchronous interaction, learning management systems (LMS) for content administration, and multimedia resources to enhance learning. These concepts, all elements of the educational model, are described in the following sections under the learning and teaching headings. 


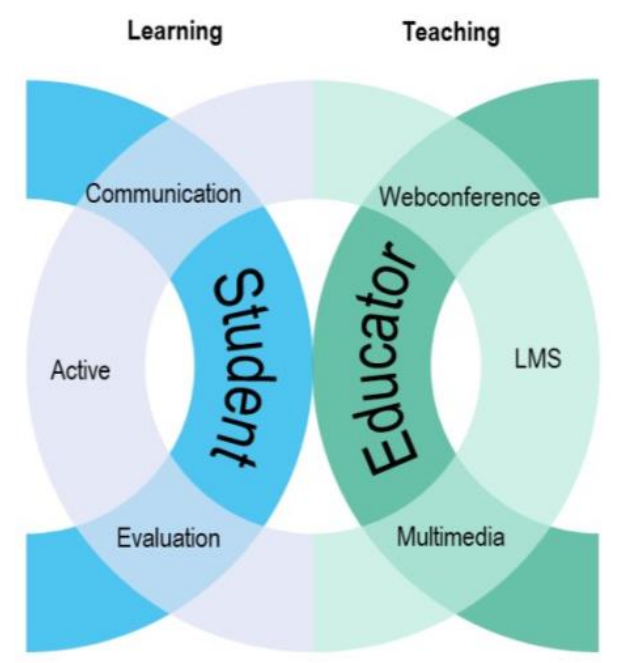

Figure 1. Digital education model (graphic designed by the authors)

\section{Learning}

Learning is the result of improved capabilities in knowledge and behaviours as a result of an experience (King et al., 2001). Digital experiences for students have changed the paradigm of learning (PérezVillalobos et al., 2021). The proposed model requires incorporating educational resources and practices for communication, active learning, and evaluation. The Organisation for Economic Co-operation and Development (OECD) emphasises the differences among students' motivations and skills to learn independently online than the ones used in face-to-face environments. Therefore, it has become imperative to implement effective education responses to address lack of engagement in this delivery format (Reimers $\&$ Schleicher, 2020).

\section{Communication}

Organisations such as the OECD encourage enhanced communication and collaboration among students to foster mutual learning and wellbeing (Sharif \& Magrill, 2015). However, it is vital to have available channels for interpersonal relationships among distant classmates and faculty (Eraña-Rojas \& López, 2021; Mendez-Reguera \& López Cabrera, 2020a). To address this, there are several possibilities including social media interaction, online forums, synchronic teamwork, or specific apps for collective participation (Mendez-Reguera \& López Cabrera, 2020b). Besides these open networks, there are specific forums to share experiences and learning (O'Connor-Córdova et al., 2021). For example, the discussion forums in massive open online courses (MOOCs) represent a unique opportunity for insight into learning communities because of the lack of instructor presence. During synchronous online classes, it is also essential to promote teamwork among participants. Breakout rooms, online surveys, polls, and debates are strategies to induce collaboration facilitated by the faculty member (Eraña-Rojas \& López, 2021). Licorish et al. (2018) recommend interactive technology with a game-based approach to enhance classroom dynamics, engagement, and overall collaborative learning experience.

\section{Active learning}

Active learning is present when learning and teaching methods are in place to put the student in charge of their own learning through meaningful activities that take knowledge to action (Olivares et al., 2019). The student becomes the main character of the teaching-learning process by inquiring, discovering, and proposing solutions to problems or working on projects. Olivares et al. (2019) describe active learning as based on three self-direction elements: learning strategies, motivation, and continuous improvement, all of which might be considered for course design. According to Bei et al. (2019) a distance program could create the conditions for learning autonomy considering the following parameters: (a) setting realistic goals to meet the student's needs, (b) choosing the time and place to improve performance, and (c) planning details for completing their learning goals. 


\section{Evaluation}

Evaluation and assessment of distance learning education represent a challenge for faculty members. The OECD (2020) recommended incorporating some solutions to identify exam takers and apply technology for different exam formats. Using technology in exams is not new. Valdez-García et al. (2020) recommended evaluating students remotely through essays or open-ended questions, demanding unique and individual responses. Further, Valdez-García et al. (2020) mention the use of technology for online proctoring. Van Halem et al. (2020) found no difference between the virtual proctored examination with traditional examination considering performance, motivation, and self-regulation.

\section{Teaching}

Teaching refers to a planned and structured set of activities to achieve learning (Falloon, 2020). To do so, a teacher must be prepared and experienced in many skills such as pedagogy and technology adoption. The COVID lockdown of schools demanded educators to be skilled in new digital competencies (Girardet, 2020). Regarding different ages or educational levels, everyone needed to engage in online instruction. Besides qualifications in their settings and disciplinary fields, educators had to become skilled in educational technology (Joao \& Carvalho-Filho, 2020). Educators required training on necessary digital skills to their previous educational innovation experiences in three main areas: web conference for synchronous interaction, LMSs for content organisation, and multimedia resources to complement learning (Lim et al., 2009).

\section{Web conferencing}

Web conferencing platforms allow instructors and students to connect and interact with peers from different locations using voice over internet protocols to share audio and video (Hurst, 2020). Live synchronous meetings help clarify problems, decrease the learner's isolation, and improve the teacher's social presence (Lowenthal et al., 2020). Some of the features that teachers can use to complement distance sessions are screen sharing to showcase videos or documents for students to analyse. Educators can also connect to other devices such as tablets or digital blackboards to demonstrate an experiment or make notes. Although these sessions may have advantages, poor administration and direction can result in frustration (Lewis et al., 2020). Educators should design and plan the educational experience to prepare contingency actions in case of unexpected technological glitches.

\section{Learning management systems}

LMSs are a management tool and system for the administration of educational material. They support asynchronous activities, from course planning to conduct of classes and assessments (Sezer \& Yilmaz, 2019). These platforms help educators distribute learning materials, perform evaluations, and host discussion forums for interaction (Mendez-Reguera \& López Cabrera, 2020b). Although online platforms are not new, migration to remote education during the coronavirus pandemic required teachers to provide more detailed information, instructions, and resources (Ohliati \& Abbas, 2019). Teachers were required to create pages, share documents, facilitate assignments, and provide feedback from grading within LMS.

\section{Multimedia}

Multimedia resources integrate audio, video, text data, and images, either created by educators or curated from online content (Sharma et al., 2018). Educators record videos, create audiovisual content, and edit clips to integrate images or sounds. These resources allow students to learn, improve, update their knowledge, and test themselves (Savov et al., 2019).

Medical schools now need to be aware and ready to transition from emergency learning to online education to continue their social responsibility commitment to guaranteeing quality education. Some of the challenges are, for example, how to assure that students are prepared to deliver bad news to a recently diagnosed cancer patient, how to ensure that learners have achieved mastery of complex surgical procedures, or what methods will be able to be used to remotely contribute to their professional identity formation. These complex tasks of the teaching and learning process rely heavily on presence-based interaction, as the community facilitates environments in which the social dimension of learning takes place (Mendez-Reguera \& López Cabrera, 2020a). 


\section{Material and methods}

At the beginning of the pandemic crisis and COVID-19 lockdown, there was a major concern from both Tecnologico de Monterrey and the School of Medicine and Health Sciences authorities to guarantee education continuity. It became imperative to support educators with proper training and infrastructure, but first, their preparedness needed to be understood. Therefore, the research questions for this study were:

- What digital tools from the digital education model do educators master for emergency remote education? and,

- How do they feel about their competence level in digital education?

\section{Design}

The experiment design was quantitative, descriptive, and cross-sectional. A quantitative approach was used to analyse the digital skills of the educators of health care professions at a private, not-for-profit university. The timing of the study was when the university suddenly changed to online education at the beginning of the crisis and lockdown, during the last week of March 2020. Since the institution is highly committed to educators' training and guidance on their transition for distance education, it was vital to identify each educator's different readiness levels to perform on the digital model. A new instrument was designed through a process that considered some of the key steps on developing surveys for medical education (de Leeuw et al., 2019). The instrument was presented remotely through a web-based survey platform.

\section{Sample}

A total of 497 teachers from the School of Medicine and Health Sciences participated in the self-assessment. Inclusion criteria for participants was to have a medicine or health sciences background and have completed graduate studies. The participants were 260 men and 297 women, with 388 being part-time and 109 fulltime. Participants were located in different cities where there the university has campuses: 290 were from Monterrey, 98 from Guadalajara, 97 from Mexico City, and 12 from Chihuahua.

\section{Instrument}

The first step to develop the survey to conduct the self-assessment of educators was to conduct a literature review to identify constructs presented in the digital education model section. The second step consisted of holding different sessions with representatives of each of the schools that are part of the university where the study was conducted. The following step considered the items, designed and analysed by the school representatives in the second step. The items embodied the knowledge, skills, and attitudes required in the digital education model (Figure 1). Expert assessment reduced the original instrument to a list of 44 skills, organised into six elements: communication, active learning, evaluation, web conferencing, LMS, and multimedia. These skills are presented in Table 1.

Table 1

Survey to assess educators preparedness for a digital education model

\begin{tabular}{|c|c|c|c|}
\hline Element & & Item & $\begin{array}{c}\text { Check if } \\
\text { YES }\end{array}$ \\
\hline Communication & $\begin{array}{l}1 . \\
2 .\end{array}$ & $\begin{array}{l}\text { I know how to instantly census group opinion through short polls. } \\
\text { I can generate breakout rooms for teams during a synchronous } \\
\text { web conference session. } \\
\text { I know how to perform individual or group counseling sessions } \\
\text { online. } \\
\text { I know how to use social media for formal and effective } \\
\text { communication and interaction with my students. } \\
\text { I use apps to stimulate game contests or competitions } \\
\text { I know how to moderate the interaction of students in class using } \\
\text { microphones, chat, among others. } \\
\text { I can create online quizzes or surveys to collect group information } \\
\text { (Mentimeter, Google forms, Kahoot, etc.). }\end{array}$ & $\begin{array}{l}\square \\
\square \\
\square\end{array}$ \\
\hline
\end{tabular}




\begin{tabular}{|c|c|c|c|}
\hline & 9. & $\begin{array}{l}\text { I can manage the cloud tools to share information and generate } \\
\text { collaborative construction dynamics (Google Apps, One Drive, } \\
\text { etc.). } \\
\text { I know how to organise and moderate digital spaces for } \\
\text { asynchronous and synchronous interaction (Slacks, Socrative, } \\
\text { Padlet, etc.). }\end{array}$ & $\square$ \\
\hline \multirow[t]{5}{*}{ Active learning } & 10. & $\begin{array}{l}\text { I know how to plan synchronous class sessions (objectives to be } \\
\text { achieved, dynamics, activities, and time distribution). }\end{array}$ & $\square$ \\
\hline & 11. & $\begin{array}{l}\text { I can identify the relevance of activities and estimate the time it } \\
\text { takes students to perform them in the digital context. }\end{array}$ & $\square$ \\
\hline & 12. & $\begin{array}{l}\text { I use active learning strategies to keep students motivated in a } \\
\text { synchronous session. }\end{array}$ & $\square$ \\
\hline & 13. & $\begin{array}{l}\text { I can design asynchronous activities that stimulate learning } \\
\text { through collaboration. }\end{array}$ & $\square$ \\
\hline & 14. & $\begin{array}{l}\text { I can adapt quickly to technological glitches so they would not } \\
\text { prevent me from continuing a session. }\end{array}$ & $\square$ \\
\hline \multirow[t]{10}{*}{ Evaluation } & 15. & $\begin{array}{l}\text { I know how to use automated tools to detect plagiarism in my } \\
\text { course activities. }\end{array}$ & $\square$ \\
\hline & $\begin{array}{l}16 . \\
17 .\end{array}$ & $\begin{array}{l}\text { I can create quizzes with closed questions for automatic review. } \\
\text { I know how to add control and restriction mechanisms for exams } \\
\text { (Respondus Lockdown browser). }\end{array}$ & $\square$ \\
\hline & 18. & $\begin{array}{l}\text { I know how to add monitor mechanism for exams (Respondus } \\
\text { Monitor). }\end{array}$ & $\square$ \\
\hline & 19. & $\begin{array}{l}\text { I can apply various strategies and technological tools to prevent } \\
\text { faults in academic integrity in class. }\end{array}$ & $\square$ \\
\hline & 20. & I can grade activities and assignments using rubrics. & \\
\hline & 21. & I can create tests with open ended questions. & $\square$ \\
\hline & 22. & $\begin{array}{l}\text { I know how to provide feedback in multimodal format (text, audio } \\
\text { and / or video). }\end{array}$ & $\begin{array}{l}\square \\
\square\end{array}$ \\
\hline & 23. & $\begin{array}{l}\text { I know how to implement formative assessment strategies both on } \\
\text { the platform and in other technological tools (simulators, } \\
\text { portfolios, applications, among others). }\end{array}$ & $\square$ \\
\hline & 24. & $\begin{array}{l}\text { I know how to add restrictions for exams (Respondus Lockdown } \\
\text { browser). }\end{array}$ & $\square$ \\
\hline & 25. & $\begin{array}{l}\text { I can apply various strategies and technological tools to prevent } \\
\text { faults in academic integrity in class. }\end{array}$ & $\square$ \\
\hline \multirow[t]{7}{*}{ Webconference } & 26. & I know how to share my screen to support documents. & $\square$ \\
\hline & 27. & I can share the video or audio from my computer. & $\square$ \\
\hline & 28. & $\begin{array}{l}\text { I know how to mark students' attendance without having to take a } \\
\text { roll during the session. }\end{array}$ & $\square$ \\
\hline & 29. & I can record the session to share with my students later. & $\square$ \\
\hline & 30. & $\begin{array}{l}\text { I can use a digital blackboard or other mobile devices to explain a } \\
\text { concept. }\end{array}$ & $\square$ \\
\hline & 31. & I know how to handle students who virtually "raise their hands". & $\square$ \\
\hline & 32. & $\begin{array}{l}\text { I know how to disable audio, video, or the presence of someone } \\
\text { causing inconvenience in the session. }\end{array}$ & $\square$ \\
\hline \multirow[t]{8}{*}{ LMS } & 33. & I can post announcements and send messages to my students. & $\square$ \\
\hline & 34. & I can create pages with content of my own. & $\square$ \\
\hline & 35. & $\begin{array}{l}\text { I can publish and share documents, images, videos, or other } \\
\text { resources. }\end{array}$ & $\square$ \\
\hline & 36. & I can design and use assessment rubrics for activities. & $\square$ \\
\hline & 37. & I know how to use the grade book. & $\square$ \\
\hline & 38. & I can create discussion forums and moderate student contributions. & $\square$ \\
\hline & & $\begin{array}{l}\text { I know how to create spaces for students to deliver their } \\
\text { assignments. }\end{array}$ & $\square$ \\
\hline & 40. & I can rate activities on the LMS. & $\square$ \\
\hline
\end{tabular}




\begin{tabular}{llll}
\hline Multimedia & 41. & I can record videos using a computer or a mobile device. & $\square$ \\
& 42. & I can create audiovisual content using different apps. & $\square$ \\
& 43. I can edit clips integrating images, sounds, etc. & $\square$ \\
& 44. I can design and create interactive presentations. & $\square$ \\
\hline
\end{tabular}

All participants completed the survey (Table 1). Additionally, at the end of the survey participants ranked themselves in three competence levels. Each participant selected only one option as overall self-perception performance: (1) novice - require close guidance, (2) competent but require occasional advice, or (3) highly competent.

Regarding the analysis of the survey results, it is important to note that participants would check the box of the skills they believed they put in practice. For each element or subscale of the instrument, a percentage of acquisition was calculated. For example, in the communication element there are nine items, therefore each item refers to a $11.11 \%$ of the readiness of the participant in that skill. Another example is multimedia, which has four items, therefore each item accounts for $25 \%$ of the readiness of the participant in that skill.

\section{Analysis}

For the readiness analysis, a percentage of skills acquisition was calculated for each of the elements described in the model. The ranked competence level also contrasted the assessment of the participants. Using descriptive statistics, trends were analysed by item and by each of the elements of the digital education model. Several mirror studies were performed for other schools (engineering, architecture, social sciences, business, humanities) at the same university with the same instrument.

\section{Ethical considerations}

Participation in the study was voluntary, and each participant granted informed consent for the information to be used for educational innovation. Regarding ethics in research, institutional representatives authorised the study to be conducted and granted an IRB exception.

\section{Results}

According to results, the participants were more prepared for the web conference tools (88.0), active learning (78.8), and multimedia (71.1) elements of the digital education model. They perceive themselves least prepared in Evaluation (57.8), LMS (69.1), and Communication (69.9). As shown in Figure 2, the self-assessment stratified participants into three competency levels: novice $13.3 \%$, competent $75.1 \%$, and highly competent $11.7 \%$. The reported confidence of the participants for being competent and highly competent in health science was slightly below those obtained in other schools: competent $(76.3 \%)$, and highly competent (16.5\%), although the interaction effect was not statistically significant ( $\mathrm{p}>.05)$. 


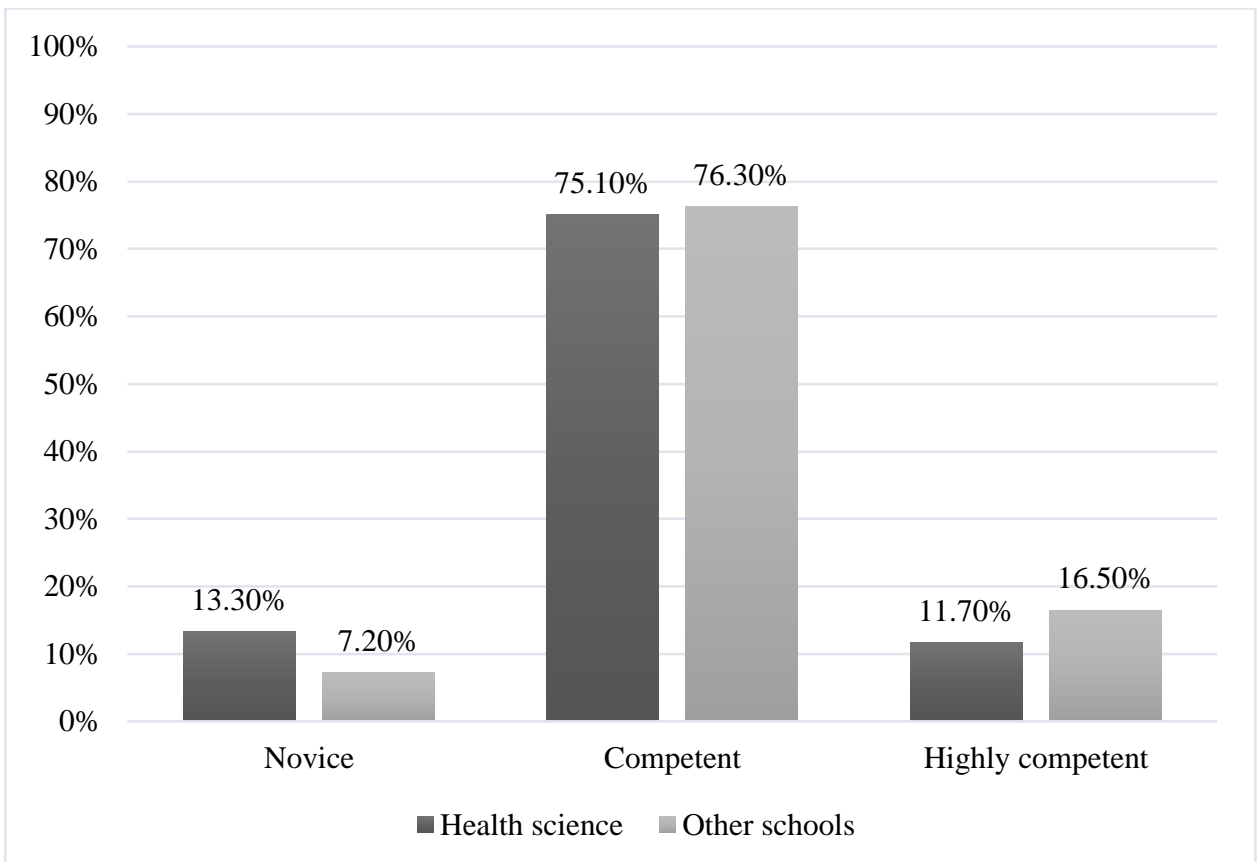

Figure 2. Comparison on self-assessment between health science educators and the ones on other schools

The different level of competence groups consistently had different levels of readiness that influence their confidence to apply the digital education model. The mean in their skills was aligned with their competence level: the novice group had a mean of 48.8 points, competent 76.7 points, and highly competent 92 points. Results show that participants self-ranked consistently according to their skills, this congruency can be seen in Figure 3 which integrates the mean scores by the teaching and learning sides of the model.

Highly competent

novice. Require close guidance
Competent but require occasional advice

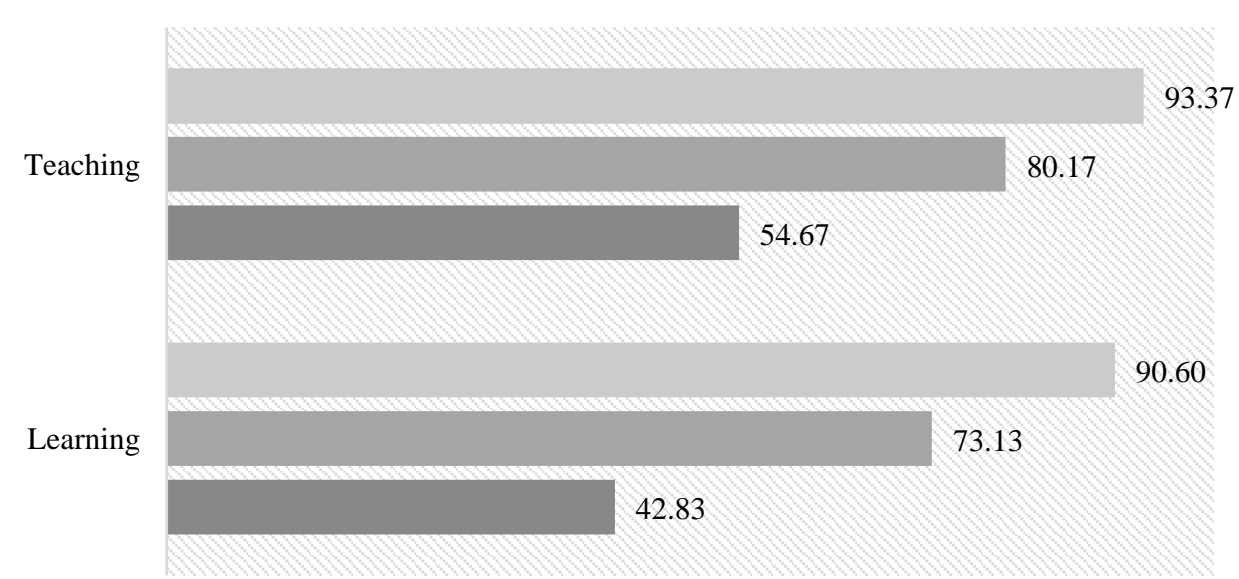

Figure 3. Congruence on educators self-assessment and the skills evaluation using the survey

In Table 2 more detail can be seen for the results of each element of the model regarding the corresponding educator group: novice, competent, or highly competent. 
Table 2

Mastery of digital education skills

\begin{tabular}{clcccrr} 
Mastery of digital education skills & \multicolumn{1}{c}{ Element } & $\begin{array}{c}\text { Novice. } \\
\text { Require } \\
\text { close } \\
\text { Puidance }\end{array}$ & $\begin{array}{c}\text { Competent but } \\
\text { require } \\
\text { occasional } \\
\text { advice }\end{array}$ & $\begin{array}{c}\text { Highly } \\
\text { competent }\end{array}$ & $\begin{array}{r}\text { Total } \\
\text { mean }\end{array}$ & $\begin{array}{r}\text { Standard } \\
\text { deviation }\end{array}$ \\
\hline Learning & Communication & 42.9 & 73.8 & 93.1 & 69.9 & 20.6 \\
\cline { 2 - 7 } & Active learning & 55.5 & 84.7 & 96.2 & 78.8 & 17.1 \\
\cline { 2 - 7 } Teaching & Evaluation & 30.1 & 60.9 & 82.5 & 57.8 & 21.5 \\
\hline & Web & 75.1 & 91.1 & 97.8 & 88.0 & 9.5 \\
\cline { 2 - 7 } & conferencing & 41.9 & 75.3 & 90.1 & 69.1 & 20.1 \\
\cline { 2 - 7 } & LMS & 47.0 & 74.1 & 92.2 & 71.1 & 18.5 \\
\hline Sultimedia & 48.8 & 76.7 & 92.0 & & \\
\hline
\end{tabular}

Analysis of the learning elements that depended primarily on student interaction, reveled the highest preparation was related to active learning. The novice group obtained a mean of 55.5, the competent group 84.7, and highly competent a 96.2 score. Face-to-face education has prepared educators to implement new educational approaches that integrate students' activities and engage with self-directed learning. For example, participants have experience in action learning and challenge-based learning activities design, considering context-rich designs with training partners in research or industry(Olivares et al., 2019). The lowest score was computed on evaluation; the mean in the novice group was 30.1, the competent was 60.9, and the highly competent reported 82.5. It was also the element in which the higher standard deviation was found, a value of 21.5. The result was consistent with the literature, as assessment in distance education models using traditional approaches tend to yield more plagiarism claims (Eraña-Rojas et al., 2020). Valdez et al. (2020) recommended evaluating students remotely through activities that demonstrate a profound reflection over the topics, such as essays or open-ended questions.

The highest preparation across the different groups was found on web conference skills. The novice group's mean was 75.1, competent 91.1, and highly competent 97.8, with the lowest dispersion, observed in the standard deviation of 9.52 . As soon as the pandemic news started to be shared, the university began offering workshops on using the different software available in the market. The participants reported that they felt confident in how to use these technologies and their various features. The lowest-ranked skill in both the novice 41.9 and highly competent group 90.1 was the LMS element. The competent group selected the multimedia element as the lowest ranked 74.1.

\section{Discussion}

This study focused on assessing educators' skills to assure that the educational services in the pandemic continued through a digital education model. Through an online survey which targeted educators from the School of Medicine and Health Sciences at Tecnologico de Monterrey, we found that there seemed to be an agreement about educators readiness to implement different active learning strategies, despite being in a distance education model. The COVID-19 precipitated transition to a digital education model created the conditions for realistic learning goals and analysis for continuous improvement (Bei et al., 2019). For example, some courses were re-oriented to focus on COVID-19 topics during pregnancy, childhood, or adulthood where students proposed educational material for health promotion.

The results of this study show that without a doubt, web conference preparedness has become a given skill for educators across the globe. The mastery of this technology is a strategy to build a social presence to reach students wherever they are (Lowenthal et al., 2020). However, it is vital that teachers also consider worst-case scenarios and prepare contingency plans for intermittent internet signal or electricity power downs. Poor administration of online sessions might result in participants' frustration and diminish the motivation for the model (Lewis et al., 2020). Web conferencing tools are now being applied not only for theoretical courses but also for patients' medical orientation. We believe that as part of the forced transition, both educators and learners have become proponents of the advantages of adopting technology as part of regular practice. 
On the other hand, and not surprisingly, the results of the study showed that evaluation had the lowest score. Although computer-adaptive tests, online proctoring, and other assessment tools have been around for decades for admission, certification, and other high-stake tests, it seems that there is still a gap in the implementation of those applications in regular courses. Medical educators struggled to assess clinical competencies remotely, especially those that required manual and procedural skills. For example, first aid training was re-designed as an online course applying simulation strategies with resources that students could find at their homes, but assessing performance at distance still represented a high effort for educators, especially when compared with the face-to-face format.

\section{Limitations}

There were several limitations in the study, as it was a single institution and one school only, the results might not represent educators in other regions, even in the same country. However, the study can provide insights for conducting a larger investigation based on the developed survey. Also, the objective was to provide rapid information as a diagnostic for prioritising training needs. Other limitations came as part of the cross-sectional design selected for the study, for example no follow up was performed on how the educators evolved as they gained more practice and experience in remote teaching. As a further limitation of the study, the results presented here reflect participants' self-perceptions and not the participants' actual performance.

Educators have learned about how to deliver content, but also about how to engage learners in their disciplines. Future studies could dwell on the transformation that educators made due to the digital educational model. Some of these transformations might refer on how they became proponents of online or distance learning formats. Others more on the practical studies could investigate how to integrate different technologies. Further there could be research interest on understanding which content could remain in a distance learning format, and which themes need to be prioritised for face-to-face interactions.

\section{Conclusion}

Before this study, there was limited information about teachers' skills in performing for online education. This self-assessment study has represented an opportunity at several levels. As an institutional effort, faculty development programs have been updated to address new requirements. The educators selfassessment on digital skills allowed the university leaders to adapt the training programs and designate staff teams to support the educators once classes restarted. As groups, the highly competent educators supported other peers on learning communities to improve online education quality nationwide regardless of disciplines or location. Since the School of Medicine and Health Sciences is located on four different campuses, the digital educational model has improved collaboration among teachers from different disciplines or areas.

At the individual level, the questionnaire invites reflection by the educator on how to improve their digital performance. The digital educational model is however expected to be a temporary solution during the pandemic since medical training requires complementary procedural skills and personal contact with patients. The survey instrument was designed and implemented in the week following the start of the COVID-19 pandemic: a time of real crisis and uncertain climate. Future work would be developed, considering more structured methods. Although the self-assessment instrument was developed for our study conducted at the beginning of the lockdown, there is potential for the instrument to aid in recruitment, development, and promotion for educators in higher education institutions willing to have distance education as hybrid or blended models, now considered the new normal.

\section{References}

Abreu-Hernández, L., Valdez-García, J., Esperón-Hernández, R., \& Olivares-Olivares, S. (2020). El reto de COVID-19 respecto a la responsabilidad social de las escuelas de medicina: nuevas perspectivas profesionales y humanas. Gaceta Médica de México, 156(4), 311-316. https://doi.org/10.24875/GMM.20000306

Bates, A. (2020). Teaching in a digital age: Guidelines for designing teaching and learning. Tony Bates Associates. 
Bei, E., Mavroidis, I., \& Giossos, Y. (2019). Development of a scale for measuring the learner autonomy of distance education students. European Journal of Open, Distance and e-Learning, 22(2). https://doi.org/10.2478/eurodl-2019-0015

Bozkurt, A., \& Sharma, R. (2020). Emergency remote teaching in a time of global crisis due to CoronaVirus pandemic. Asian Journal of Distance Education, 15(1), 1-4. https://doi.org/10.5281/zenodo.3778083

de Leeuw, R, Westerman, M., Walsh, K., \& Scheele, F. (2019). Development of an instructional design evaluation survey for postgraduate medical e-learning: Content validation study. Journal of Medical Internet Research, 21(8), e13921. https://www.jmir.org/2019/8/e13921

Eraña, I. E., López, D. M., Díaz, R., \& López, M. V. (2020). En nuestra escuela eso no pasa: percepciones sobre la deshonestidad académica con estudiantes de medicina. Educación Médica, 21(2), 100-105. https://doi.org/10.1016/j.edumed.2018.05.014

Eraña-Rojas, I. E., \& López, M. (2021). Meaningful dialogue with students amid the pandemic. Medical Education, 55(5), 654-655. https://onlinelibrary.wiley.com/doi/full/10.1111/medu.14490

Falloon, G. (2020). From digital literacy to digital competence: The teacher digital competency (TDC) framework. Educational Technology Research and Development, 68(1), 2449-2472. https://doi.org/10.1007/s11423-020-09767-4

Galusha, M. J. (1997). Barriers to learning in distance education. International Computing and Technology, 5(3-4), 6-14.

Girardet, H. (2020). A manifesto for the coronacene. The Ecologist: Journal for the Post-Industrial Age. https://heecologist.org/2020/may/21/manifesto-coronacene

Hurst, E. (2020). Web conferencing and collaboration tools and trends, Journal of Hospital Librarianship, 20(3), 266-279. https://doi.org/10.1080/15323269.2020.1780079

Joao, M., \& Carvalho-Filho, M. (2020). Una nueva época para la educación médica después de la COVID, Fundación en Educación Médica, 23(2), 55-57. https://dx.doi.org/10.33588/fem.232.1052

King, F. B., Young, M. F., Drivere-Richmond, K., \& Schrader, P. G. (2001). Defining distance learning and distance education. Educational Technology Review, 9(1), 1-14.

Lewis, P., Catanzano, T., Davis, L., \& Jordan, S. (2020). Web-based conferencing: What radiology educators need to know. Academic Radiology, 27(3), 447-454. https://doi.org/10.1016/j.acra.2019.05.017

Licorish, S., Owen, H., Daniel, B., \& George, J. (2018). Students' perception of Kahoot!'s influence on teaching and learning. Research and Practice in Technology Enhanced Learning, 13(9). https://doi.org/10.1186/s41039-018-0078-8 2018

Lim, E., Oh, V., Koh, D., \& Seet, R. (2009). The challenges of "continuing medical education" in pandemic era. Ann Acad Med Singapore, 38(8), 724-726.

López, M., Olivares, S., \& Heredia, Y. (2020). Professional culture in medical schools: A medical educator interpretation. Medical Science Educator, 30(1), 281-286. https://doi.org/10.1007/s40670019-00896-X

López, M., \& Valdez-García, J. (2019). Organizational philosophy and planning: The keys to the adoption of educational technology. In M. A. Clausen (Ed.), A closer look at educational technology (pp. 113-129). Nova Science Publishers.

López Cabrera, M. V., Hernandez-Rangel, E., Mejia, G., \& Fuentes, J. L. (2019). Factores que facilitan la adopción de tecnología educativa en escuelas de medicina. Educación Médica, 20(1), 3-9. https://doi.org/10.1016/j.edumed.2017.07.006

Lowenthal, P., Borup, J., West, R., \&Archambault, L. (2020). Thinking beyond Zoom: Using asynchronous video to maintain connection and engagement during the COVID-19 pandemic. Journal of Technology and Teacher Education, 28(2), 383-391.

Mendez-Reguera, A., \& López, M. (2020a). Coronabunker: Let's just not talk about it. Medical Education, 54(11), 1053-1054. https://doi.org/10.1111/medu.14306

Mendez-Reguera, A., \& López, M. (2020b). Engaging my gen Z class: Teaching with memes. Medical Science Educator, 30(4), 1357-1358. https://doi.org/10.1007/s40670-020-01078-w

O’Connor-Córdova, M., Kumar Peddinani, B., \& López, M. (2021). The digital educational model: Transformation of a medical program amid the COVID-19 pandemic. In D. Chatham (Ed.), Advancing online course design and pedagogy for the 21st century learning environment (pp. 78-92). IGI Global.

Ohliati, J., \& Abbas, B. (2019). Measuring students' satisfaction in using learning management system. International Journal of Emerging Technologies in Learning, 14(4), 180-189.

https://doi.org/10.3991/ijet.v14.i04.9427 
Olivares, S., Adame, E., Treviño, J., López, M., \& Turrubiates, M. (2019). Action learning: Challenges that impact employability skills. Higher Education, Skills and Work-Based Learning, 10(1), 203-216. https://doi.org/10.1108/HESWBL-07-2019-0097

Organisation for Economic Co-operation and Development (2020). Education responses to covid-19: Embracing digital learning and online collaboration. https://www.oecd.org/coronavirus/policyresponses/education-responses-to-covid-19-embracing-digital-learning-and-online-collaborationd75eb0e8/

Peña-Martínez, H., \& López, M. (2021). The COVID-19 pandemic: The 2020 cataclysm for traditional medical education. Educación médica, 22(1), 39-40. https://doi.org/10.1016/j.edumed.2020.11.006

Pérez-Villalobos, C., Ventura-Ventura, J., Spormann-Romeri, C., Melipillán, R. Jara-Reyes, C., ParedesVillarroel, X., Rojas-Pino, M., Baquedano-Rodríguez, M., Castillo-Rabanal, I., Parra-Ponce, P., Bastías-Vega, N., Alvarado-Figueroa, D., \& Matus-Betancourt, O. (2021). Satisfaction with remote teaching during the first semester of the COVID-19 crisis: Psychometric properties of a scale for health students. PLOS ONE, 16(4), e0250739. https://doi.org/10.1371/journal.pone.0250739

Reimers, F., \& Schleicher, A. (2020). A framework to guide an education response to the COVID-19 pandemic of 2020. https://www.aforges.org/wp-content/uploads/2020/04/framework.pdf

Sandars, J., Correia, R., Dankbaar, M., de Jong, P., Goh, P., Hege, I., Masters, K., Oh, S. Y., Patel, R., Premkumar, K., Webb, A., \& Pusic, M. (2020). Twelve tips for rapidly migrating to online learning during the COVID-19 pandemic. MedEd Publish, 9(1), 82-92. https://doi.org/10.15694/mep.2020.000082.1

Savov, S., Antonova, R., \& Spassov, K. (2019). Multimedia applications in education. In A. Al-Masri, \& K. Curran (Eds.) Smart technologies and innovation for a sustainable future. Advances in science, technology \& innovation (IEREK Interdisciplinary series for sustainable development) (pp. 263-271). Springer. https://doi.org/10.1007/978-3-030-01659-3_30

Sezer, B., \& Yilmaz, R. (2019). Learning management system acceptance scale (LMSAS): A validity and reliability study. Australasian Journal of Educational Technology, 35(2), 15-31. https://doi.org/10.14742/ajet.3959

Sharif, A., \& Magrill, B. (2015). Discussion forums in MOOCs. International Journal of Learning, Teaching and Educational Research, 12(1), 119-132.

Sharma, G., Shakya, S., \& Thapa, L. (2018). Distributed multimedia system for distance education. Journal of the Institute of Engineering, 15(1), 14-24.

Valdez-García, J., López, M., Jiménez, M., Díaz, J., Dávila, J., \& Olivares, S. (2020). Me preparo para ayudar: respuesta de las escuelas de medicina y ciencias de la salud ante COVID-19. Investigación en Educación Médica, 9(35), 1-11. https://doi.org/10.22201/facmed.20075057e.2020.35.20230

Van Halem, N., Van Klaveren, C., \& Cornelisz, I. (2020). The effects of implementation barriers in virtually proctored examination: A randomised field experiment in Dutch higher education. Higher Education Quarterly, 75(1), 333-347. https://doi.org/10.1111/hequ.12275

Corresponding author: Mildred Lopez, mildredlopez@tec.mx

Copyright: Articles published in the Australasian Journal of Educational Technology (AJET) are available under Creative Commons Attribution Non-Commercial No Derivatives Licence (CC BY-NCND 4.0). Authors retain copyright in their work and grant AJET right of first publication under CC BYNC-ND 4.0.

Please cite as: Olivares Olivares, S. L., Lopez, M., Martinez, R., Nigenda Alvarez, J. P., \& Valdez-García, J. E. (2021). Faculty readiness for a digital education model: A self-assessment from health sciences educators. Australasian Journal of Educational Technology, 37(5), 116-127.

https://doi.org/10.14742/ajet.7105 